\title{
High-K and shoshonitic intrusions in southeastern Tibet: implications for metasomatized lithospheric mantle and enriched continental crust
}

REN-ZHI ZHU ${ }^{1}$, EWA SLABY ${ }^{2}$, MiKe FOWLER ${ }^{3}$, SHAOCONG LAI ${ }^{1 *}$, SHAOWEI ZHAO ${ }^{4}$, JIANGFENG, QIN ${ }^{1}$, WENHANG LIU ${ }^{2}$

${ }^{1}$ State Key Laboratory of Continental Dynamics, Department of Geology, Northwest University, Xi'an 710069, China

${ }^{2}$ Institute of Geological Sciences, Polish Academy of Science, 51/55, Warsaw, Poland

${ }^{3}$ School of Earth and Environmental Sciences, University of Portsmouth, PO1 3QL, United Kingdom

${ }^{4}$ Ministry of Education, Key Laboratory of Western China's Mineral Resources and Geological Engineering, School of Earth Science \& Resources, Chang'an University, $X i$ 'an 710054, China

High-potassium to shoshonitic suites are volumetrically small but widespread in various parts of the Tethyan orogen and provide key information on mantle-crust interactions. However, their spatial-temporal distribution and origin have not yet been fully constrained. A ca. $75-50 \mathrm{Ma}$ "restricted high-K to shoshonitic intrusion zone" has been identified (width ca. 20-30 km, length ca. $150 \mathrm{~km}$ ) in the central Tengchong terrane of southeastern Tibet. These lateCretaceous to early-Cenozoic intrusions have high LILE and LREE and depletion of Nb-Ta-Ti with enriched "crustal" whole-rock $\mathrm{Sr}-\mathrm{Nd}-\mathrm{Pb}$ and in situ zircon Lu-Hf isotopic signatures. Late-Cretaceous (ca.70 Ma) mafic intrusions are shoshonitic $\left(\mathrm{K}_{2} \mathrm{O}\right.$, ca. 3.3 wt.\%) with low $\mathrm{SiO}_{2}(52.0$ wt.\%), high $\mathrm{MgO}$ (ca. 5.1 wt.\%) with high-Mg\# (57), and low $\mathrm{CaO} / \mathrm{Al}_{2} \mathrm{O}_{3}(<0.50)$. They also have low $\mathrm{Ba} / \mathrm{Th}, \mathrm{Ba} / \mathrm{La}, \mathrm{Sm} / \mathrm{La}$ (all $<0.3$ ), $\mathrm{Nb} / \mathrm{Yb}$ and ${ }^{208} \mathrm{~Pb} /{ }^{206} \mathrm{~Pb}$ ratios but high $\mathrm{Hf} / \mathrm{Sm}$ $(>0.70), \mathrm{Th} / \mathrm{Yb}, \mathrm{Th} / \mathrm{La}(>0.2)$ and $\mathrm{La} / \mathrm{Sm}$, and lack negative $\mathrm{Eu}$ anomalies. Such characteristics suggest derivation from melting of sub-continental lithospheric mantle (SCLM) metasomatized by sediment-derived melts and/or fluids. The associated felsic granitic intrusions (ca. 70-50 Ma) have high $\mathrm{SiO}_{2}$, alkali content (up to 10.0 wt. $\% \mathrm{Na}_{2} \mathrm{O}+\mathrm{K}_{2} \mathrm{O}$ ) and incompatible elements, with large negative Eu anomalies, and were likely derived from the continental crust enriched by fluids released from potassic mafic magmas crystallising at depth. Thus, the SCLM acted as water donors that triggered extensive melting of enriched continental crust. Combined with other geological data, these two-stage shoshonitic intrusions record processes arising from subduction of the Neo-Tethyan ocean slab to initial collision of India-Asia, from steepening subduction to slab rollback and breakoff. 